\title{
Complex analysis of energy efficiency in operated high-rise residential building: Case study
}

\author{
Sergey Korniyenko ${ }^{1 *}$ \\ ${ }^{1}$ Volgograd State Technical University, Russia, 400005, Volgograd, Lenin avenue, 28
}

\begin{abstract}
Energy conservation and human thermal comfort enhancement in buildings is a topical issue of modern architecture and construction. The innovative solution of this problem makes it possible to enhance building ecological and maintenance safety, to reduce hydrocarbon fuel consumption, and to improve life standard of people. The requirements to increase of energy efficiency in buildings should be provided at all the stages of building's life cycle that is at the stage of design, construction and maintenance of buildings. The research purpose is complex analysis of energy efficiency in operated high-rise residential building. Many actions for building energy efficiency are realized according to the project; mainly it is the effective building envelope and engineering systems. Based on results of measurements the energy indicators of the building during annual period have been calculated. The main reason of increase in heat losses consists in the raised infiltration of external air in the building through a building envelope owing to the increased air permeability of windows and balcony doors (construction defects). Thermorenovation of the building based on ventilating and infiltration heat losses reduction through a building envelope allows reducing annual energy consumption. Energy efficiency assessment based on the total annual energy consumption of building, including energy indices for heating and a ventilation, hot water supply and electricity supply, in comparison with heating is more complete. The account of various components in building energy balance completely corresponds to modern direction of researches on energy conservation and thermal comfort enhancement in buildings.
\end{abstract}

\section{Introduction}

Energy saving and increase of energy efficiency in building is a topical issue of modern architecture and construction. The innovative solution of this problem makes it possible to enhance building ecological and maintenance safety, to reduce hydrocarbon fuel consumption, and to improve life standard of people. The requirements to increase of energy efficiency in buildings should be provided at all the stages of building's life cycle that is at the stage of design, construction and maintenance of buildings.

\footnotetext{
*Corresponding author: svkorn2009@yandex.ru
} 
Considerable contribution to the development of the energy conception of building design in Russia was made by V.N. Bogoslovsky in the area of building thermal comfort and by Yu.A. Tabunshchikov in the area of considering the building as an entire energy system [2,3]. This conception was developed in research works [4-20].

There are different ways of solving this problem.

Yu.A. Matrosov and I.N. Butovsky as well as other researchers [4-6] announced a new direction for the Russian national code that includes a performance requirement limiting buildings normalized annual heating energy.

As discussed by N.I. Vatin and A.S. Gorshkov [7-9] the problem of influence of building's thermal performance on heat-losses based on energy consumption modeling via heat balance method for energy performance of a building is of fundamental importance.

The author declares [10] that for increase in accuracy it is necessary to carry out a mathematic modeling of heat balance process in building envelopes with due account for thermal edge zones of building envelopes. For this purpose he developed the unique computing software [11]. As discussed elsewhere [12-14] based on computing software an analyses of thermotechnical defects of building components have been carried out.

Recently the problem of methodology of energy inspection in buildings was stated by many researchers [15-19].

Q.J. Kwong, N.M. Adam and B.B. Sahari [20] investigated thermal comfort and potential for energy efficiency enhancement in buildings.

The complex analysis of energy efficiency in residential and public buildings can be carried out based on design and measurement procedures. However, the absence of reliable and practically convenient methods of determination of energy indices in the Russian norms as well as considerable labour intensity of carrying out field measurements and processing of the obtained results complicate the solution of the above problem for operated high-rise residential buildings. Thus a topic of this original research is of importance.

The research purpose is complex analysis of energy efficiency in operated high-rise residential building.

The object of investigation is a residential multi-apartment building in Volgograd. Height of the building is $80 \mathrm{~m}$. Number of floors is 23 . Number of block-sections is 3 . Number of flats is 234 . There is heated basement in the building where there is a parking area and premises of engineering functions. There are offices on the first floor and engineering networks in the attic (Fig. 1a).

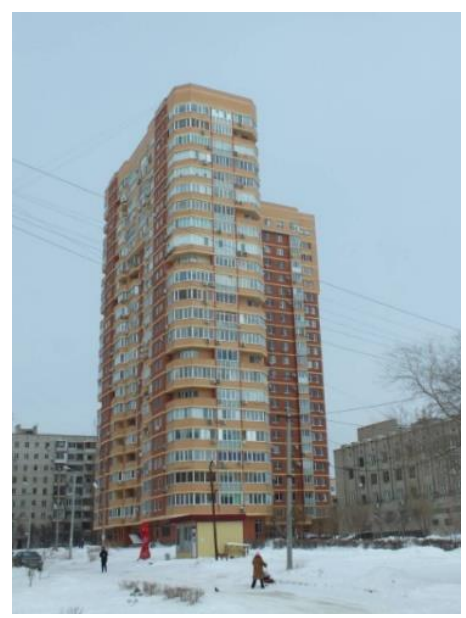

a

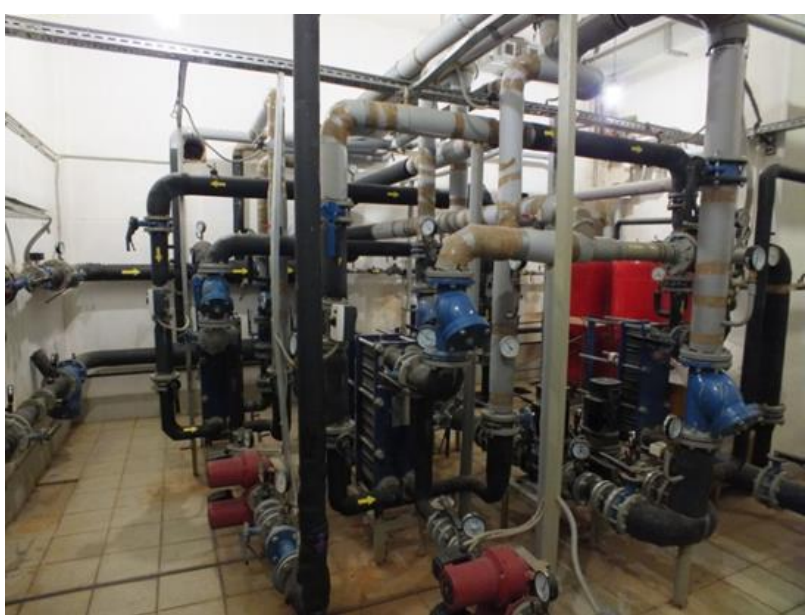

b

Fig. 1. General views of the building: $\mathrm{a}$ - general view; $\mathrm{b}$ - individual heat supply unit. 
The following geometrical data are used for design object:

- Build-up area - $1093 \mathrm{~m}^{2}$;

- Total area of the building $-25776 \mathrm{~m}^{2}$;

- Total area of apartments $-17764 \mathrm{~m}^{2}$;

- Envelope area - $19345 \mathrm{~m}^{2}$;

- Heated volume $-87000 \mathrm{~m}^{3}$;

- Glazing-to-wall ratio - 0.172;

- Building compactness ratio $-0.222 \mathrm{~m}^{-1}$.

The building was built in 2007. At the moment of energy survey the life service of the building was about 5 years.

\section{Materials and Methods}

\subsection{Climatic data}

The following climatic data are used for design object:

- Location - Volgograd, Russia;

- Geographical coordinate - N $48^{\circ}, \mathrm{E} 44^{\circ}$;

- Height above sea level - $102 \mathrm{~m}$;

- Monthly average outdoor air temperature in January $-6.9^{\circ} \mathrm{C}$ below zero;

- Monthly average outdoor air temperature in July $-23.9^{\circ} \mathrm{C}$ above zero;

- Design outdoor air temperature for heating $-22{ }^{\circ} \mathrm{C}$ below zero;

- Daily average outdoor air temperature during heating period $-2.3^{\circ} \mathrm{C}$ below zero;

- Duration of the heating period - 176 day/year;

- Heating degree-day (HDD) - $3925 \mathrm{~K} \cdot$ day/year.

\subsection{Building envelope}

Distinction between load-bearing and enclosing structures is a major feature of this design project. Load-bearing base of the building is a reinforced frame with precast framework with flat plates of slabs. There are perforated holes in slabs, filled with thermal inserts made of polyester foam, to decrease heat losses in the cold season along the outside contour of the slab. Heat protective cover of the building consists of different types of envelopes. Exterior walls are made of AAC $400 \mathrm{~mm}$ thick blocks in a form of masonry with exterior $120 \mathrm{~mm}$ thick brick facing. Interior surface of walls are plastered using complex mortar. Walls are supported floor-by-floor by plates of slabs. Brick masonry is connected to autoclaved aerated concrete blocks using flexible bonds. Double-glazed windows and balcony doors are made of PVC profiles (according to the design). Attic slabs and slabs over the basement are thermally insulated. Insulated bay-widows are assumed to increase level of natural lightning and to improve duration of insulation in rooms.

Thermal inserts made of efficient insulators are assumed to improve heat-conductive properties of the covers and the increase of heat protective properties. The estimation results of heat protection level and energy performance in the building and actual energy performance under field conditions are given below. Element-by-element estimation of heat protection indicators in the building are given in the Table 1. 
Table 1. Element-by-element heat protection in the building based on design data.

\begin{tabular}{|c|c|c|c|}
\hline \multirow[b]{2}{*}{ Building envelope } & \multicolumn{2}{|c|}{$\begin{array}{c}\text { Rated resistance to heat transfer } \mathrm{R}_{0}{ }^{\text {req }} \text {, } \\
\mathrm{m}^{2} \cdot \mathrm{K} / \mathrm{W} \text { (SP 50.13330.2012) }\end{array}$} & \multirow{2}{*}{$\begin{array}{l}\text { Estimated resistance } \\
\text { to heat transfer } R_{0} \text { des } \\
\mathrm{m}^{2} \cdot \mathrm{K} / \mathrm{W}\end{array}$} \\
\hline & $\begin{array}{l}\text { Minimum allowed } \\
\text { level of heat } \\
\text { protection }\end{array}$ & $\begin{array}{c}\text { Basic level of heat } \\
\text { protection }\end{array}$ & \\
\hline Exterior walls & 1.75 & 2.77 & 2.14 \\
\hline Windows, balcony doors & 0.42 & 0.44 & 0.54 \\
\hline Entrance doors & 0.42 & 0.44 & 0.54 \\
\hline Floor & 3.33 & 4.16 & 3.84 \\
\hline Slab over basement & 2.94 & 3.67 & 3.22 \\
\hline Slab under bay-windows & 3.33 & 4.16 & 3.56 \\
\hline
\end{tabular}

\subsection{Engineering systems}

There is a centralized heat supply, which source is an individual heat supply unit connected to outdoor heating networks. The individual heat supply unit is arranged in the basement. There is a double pipe heating system with bottom-pipe distribution and flat-by-flat perimeter distribution. Convectors with temperature regulators are used as heaters. Estimated parameters of a heat carrier for heating are $85 / 65^{\circ} \mathrm{C}$. The building is naturally ventilated. Air intake is secured through regulated window casement in living rooms and kitchens; air recovery is carried out through exhaust ventilation in kitchens and sanitary facilities. Engineering systems of buildings are equipped with metering devices for heat energy, cold and hot water and electric power (Fig. 1b).

\subsection{Energy-saving technologies in the building}

The following modern energy-saving technologies are realized in the building:

- Compact form of the building;

- Use of block-sections;

- Decrease in the area of windows according to requirements of natural illumination;

- Use of tambours at entrances to the building;

- Rational orientation of the building on sides of the horizon;

- Use of effective heat-insulating materials in the building envelope;

- Application of individual heat supply unit with automatic control of energy consumption;

- Use of energy efficient engineering systems and effective types of heaters.

The detailed description of the energy-saving activities applied in the project is given in article [11].

\subsection{Energy efficiency estimation}

The real structure of annual energy consumption in the building is complex and includes thermal energy on heating and ventilation, thermal energy on hot water supply and electrical energy supply in public place (Fig. 2).

The specific energy consumption in engineering systems during the annual period (or heating period) can be used for assessment of energy efficiency in building. The specific energy consumption is determined as ratio of the total energy consumption to the summary area of apartments. Criterion of energy efficiency in buildings is the following inequation: 


$$
\mathrm{q} \leq \mathrm{q}^{\text {bas }}
$$

where $\mathrm{q}$ - design (or actual) specific energy consumption; qbas - rated specific energy consumption.

The specific energy consumption q includes the consumption on a heating and ventilation, hot water supply and electrical energy. Generally the total energy consumption $\mathrm{Q}, \mathrm{kWh} / \mathrm{year}$, is calculated according to the formula:

$$
\mathrm{Q}=\int_{\tau_{1}}^{\tau_{2}} \mathrm{Q}_{\mathrm{h}} \mathrm{dz}+\int_{\tau_{3}}^{\tau_{4}} \mathrm{Q}_{\mathrm{hw}} \mathrm{dz}+\int_{\tau_{5}}^{\tau_{6}} \mathrm{Q}_{\mathrm{e}} \mathrm{dz}
$$

where Qh, Qhw, Qe - respectively, the heat flow on a heating, hot water supply and electric power; $(\tau 2-\tau 1),(\tau 4-\tau 3),(\tau 6-\tau 5)$ - respectively, heating, hot water supply and electrical supply periods.

The amount of thermal energy necessary for heating of the building is defined for each time point as result of summation of heat losses and heat gain, i.e. a solution of the equation of thermal balance of the building.

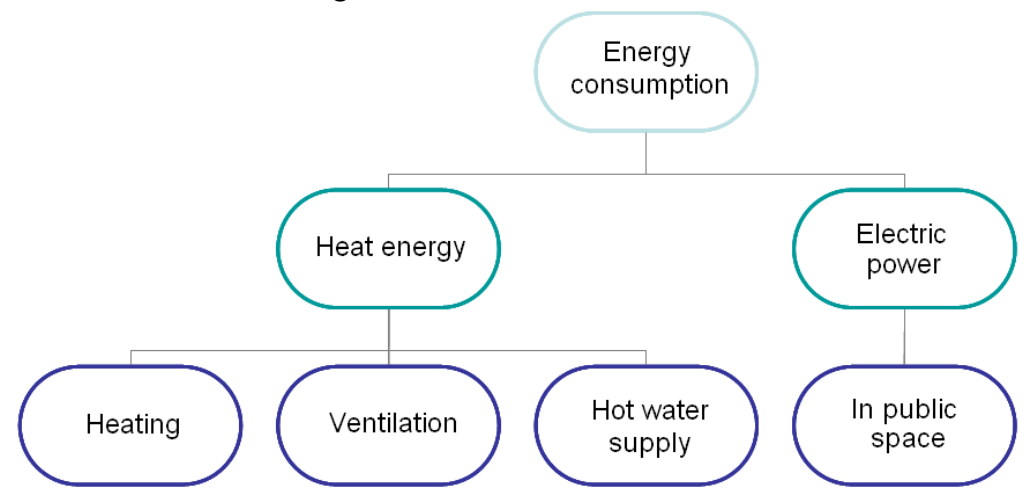

Fig. 2. Structure of annual energy consumption in the building (according to Order No. 399/Pr of Russian Ministry of Building).

Rated specific energy consumption qbas is determined for the base building which has design geometrical characteristics, minimum permissible level of building envelope thermal performance and standard engineering systems. Energy efficiency class of a building is defined on relative departure of specific energy consumption q from the rated value qbas. The computer program developed by the author makes it possible to computing building energy indices during heating period (Fig.3).

It was stated in [10] that energy consumption for heating include transmission heat loss through building envelope considering the edge zones, heat loss due to air ventilation and infiltration, indoor domestic heat generation, heat gain due to solar radiation. Preparation of initial data for computing is intuitive and easy-to-use. The calculation results in the computer program are presented in a user-friendly form. There is data base for information storage and accumulation. The computer program has modular structure that allows its further enhancement.

The measurement and registration of energy consumption indicators in the building were completed through express-method within two weeks starting on 22.12.2011 to 04.01.2012. The application of the express method allows reducing significantly the labour intensity as well as the duration of the field observation. The monitoring of the thermal 
energy consumption for heating and hot water supply was carried out separately on an automatic basis once a day according to the building communal heat meter (see figure 1b). The electrical energy consumption measurement was carried out on flat-by-flat basis taking into account the building communal meter reading.

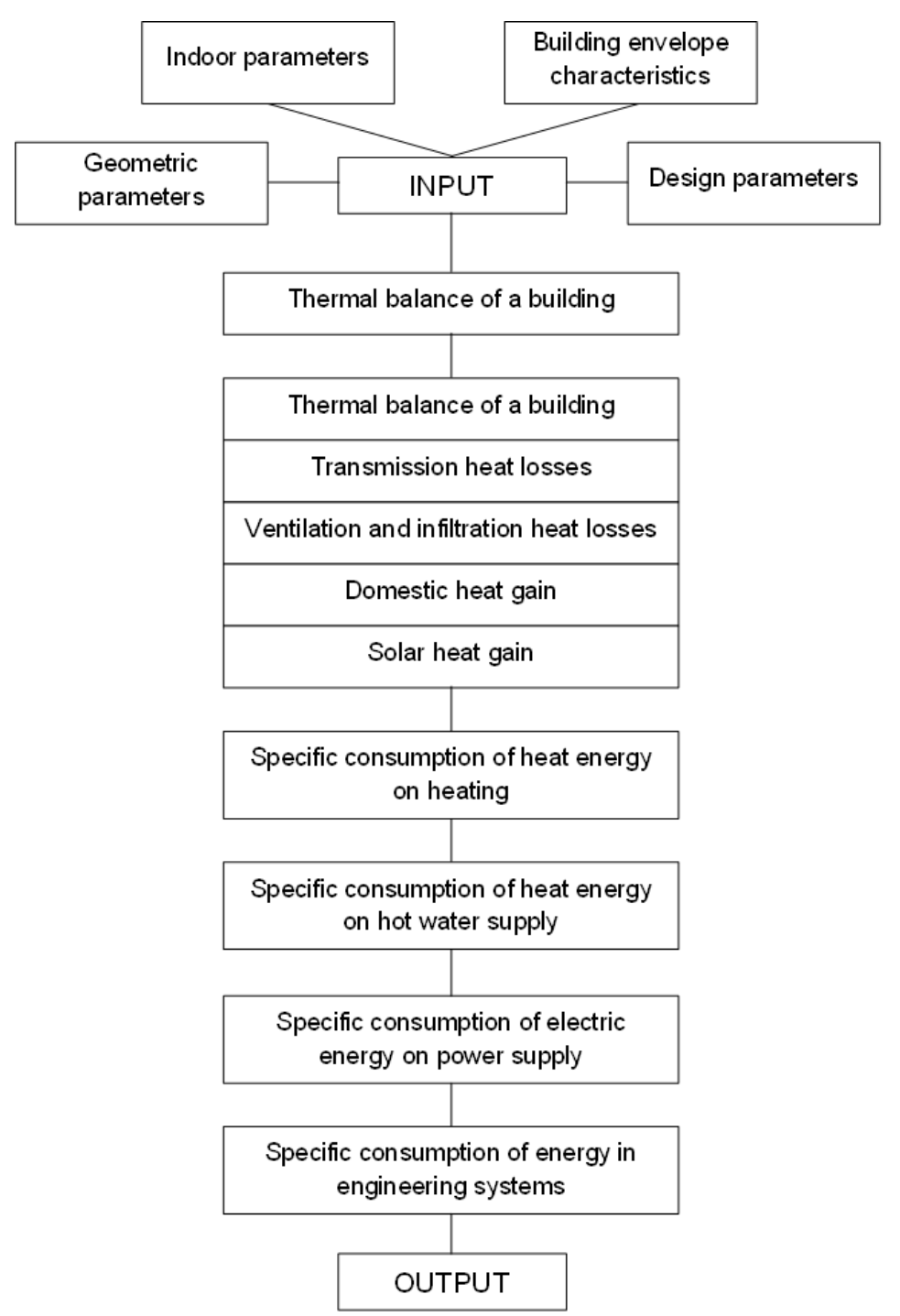

Fig. 3. Program flow chart developed by the author

Based on results of measurements the energy indicators of the building during annual period have been calculated. Dependence between a specific heating index $\mathrm{q}_{\mathrm{h}}{ }^{\prime}, \mathrm{W} /\left(\mathrm{m}^{3} \cdot \mathrm{K}\right)$, and a specific energy consumption $\mathrm{q}_{\mathrm{h}}, \mathrm{kWh} /\left(\mathrm{m}^{2}\right.$.year), on heating and ventilation of a building is calculated according to the formula:

$$
\mathrm{q}_{\mathrm{h}}=\frac{0.024 \mathrm{q}_{\mathrm{h}}^{\prime} \mathrm{V}_{\mathrm{h}} \mathrm{HDD}}{\mathrm{A}_{\mathrm{a}}},
$$


where $0.024 \mathrm{kWh} /(\mathrm{W} \cdot$ day $)$ - factor; $\mathrm{V}_{\mathrm{h}}$ - heated volume, $\mathrm{m}^{3}$; HDD - heating degree-day, $\mathrm{K} \cdot$ day/year; $\mathrm{A}_{\mathrm{a}}$ - total area of apartments, $\mathrm{m}^{2}$.

Assessment of an energy efficiency of the building is executed by two methods:

- Using the specific heating index $\mathrm{q}_{\mathrm{h}}{ }^{\prime}$ during the heating period;

- According to the specific energy consumption $\mathrm{q}_{\mathrm{h}}$ on a heating and ventilation, hot water supply and electrical energy in public space.

\section{Results and Discussion}

The results of measuring the building heating energy consumption are given below.

- Transmission heat losses index $\mathrm{q}_{\mathrm{tr}}=0.149 \mathrm{~W} /\left(\mathrm{m}^{3} \cdot \mathrm{K}\right)$;

- Ventilation and infiltration heat losses index $\mathrm{q}_{\mathrm{v}}=0.243 \mathrm{~W} /\left(\mathrm{m}^{3} \cdot \mathrm{K}\right)$;

- Domestic heat gain index $\mathrm{q}_{\mathrm{i}}=0.076 \mathrm{~W} /\left(\mathrm{m}^{3} \cdot \mathrm{K}\right)$;

- Solar heat gain index $\mathrm{q}_{\mathrm{s}}=0.037 \mathrm{~W} /\left(\mathrm{m}^{3} \cdot \mathrm{K}\right)$.

The specific actual heating index $\mathrm{q}_{\mathrm{h}}{ }^{\prime}=0.279 \mathrm{~W} /\left(\mathrm{m}^{3} \cdot \mathrm{K}\right)$.

The analysis of the results gives the following structure of thermal balance (Fig. 4a): transmission heat losses - 30\%, ventilation and infiltration heat losses $-48 \%$, domestic heat gain $-15 \%$, solar heat gain $-7 \%$. Ventilation and infiltration heat losses are the largest "specific weight" one within building thermal balance. Therefore, it is possible to increase the building energy efficiency first of all by means of reducing the ventilation and infiltration heat losses in the building.

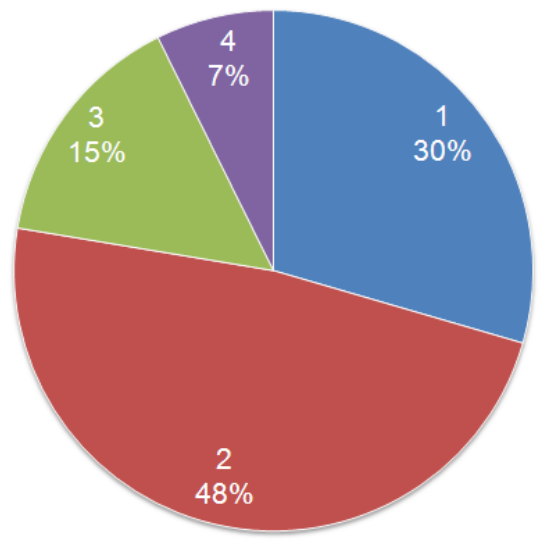

a

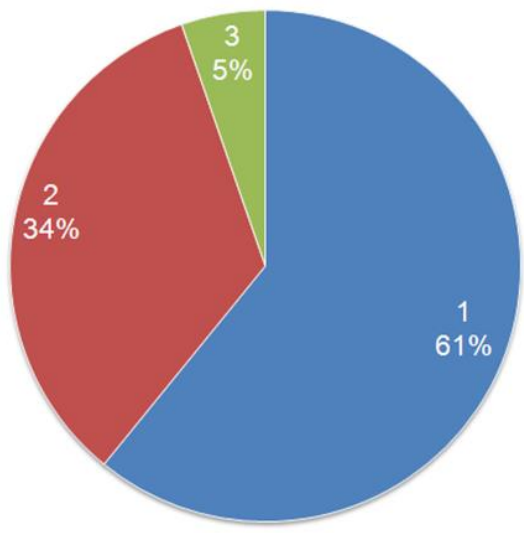

b

Fig. 4. Energy balance in the building: a - thermal balance during the heating period $(1-$ transmission heat losses; 2 - ventilation and infiltration heat losses; 3 - domestic heat gain; 4 - solar heat gain); $\mathrm{b}$ - energy consumption during the annual period ( 1 - heating; 2 - hot water supply; 3 electrical energy supply in public place).

The main reason of increase in heat losses consists in the raised infiltration of external air in the building through a building envelope owing to the increased air permeability of windows and balcony doors. It is caused by various construction defects. The actual air change rate in the building (about $0.7 \mathrm{~h}-1)$ is more than design value $(0.4 \mathrm{~h}-1)$. Minimum air change rate namin, $\mathrm{h}-1$, in the building during the heating period is calculated by simplified formula:

$$
\mathrm{n}_{\mathrm{a}}^{\min }=\frac{30 \mathrm{~m}}{\beta_{\mathrm{v}} \mathrm{V}_{\mathrm{h}}},
$$


where $\mathrm{m}-$ number of persons in the building; $\beta_{\mathrm{v}}-$ correction index; $\mathrm{V}_{\mathrm{h}}-$ heated volume.

According to the formula (4), using design data, the following value of minimum air change can be calculated: $\mathrm{n}_{\mathrm{a}}{ }^{\min }=0.23 \mathrm{~h}^{-1}$.

For ensuring the normalized air exchange at the equipment of rooms only with the exhaust shaft ventilation it is necessary to provide adjustable affluent devices in windows (thermorenovation). It is also necessary to reduce as much as possible energy consumption by external air infiltration through the building envelope.

The results of measuring the building energy indices during the annual period are given below.

- Heating index $\mathrm{q}_{\mathrm{h}}=129 \mathrm{kWh} /\left(\mathrm{m}^{2} \cdot\right.$ year $)$;

- Hot water supply index $\mathrm{q}_{\mathrm{hw}}=71.5 \mathrm{kWh} /\left(\mathrm{m}^{2} \cdot\right.$ year $)$;

- Electrical energy index (in public place) $\mathrm{q}_{\mathrm{e}}=11.3 \mathrm{kWh} /\left(\mathrm{m}^{2} \cdot\right.$ year).

The total actual energy index $\mathrm{q}=212 \mathrm{kWh} /\left(\mathrm{m}^{2} \cdot\right.$ year $)$.

The analysis of the results gives the following structure of energy consumption (see figure $4 \mathrm{~b}$ ): for heating - $61 \%$, for hot water supply $-34 \%$, for electricity supply $-5 \%$. Heating is the "heaviest" one within building energy consumption. Therefore, it is possible to increase the building energy efficiency first of all by means of reducing the thermal energy consumption for heating.

The results of energy efficiency class assessment for the building based on heating energy consumption during the heating period are given below.
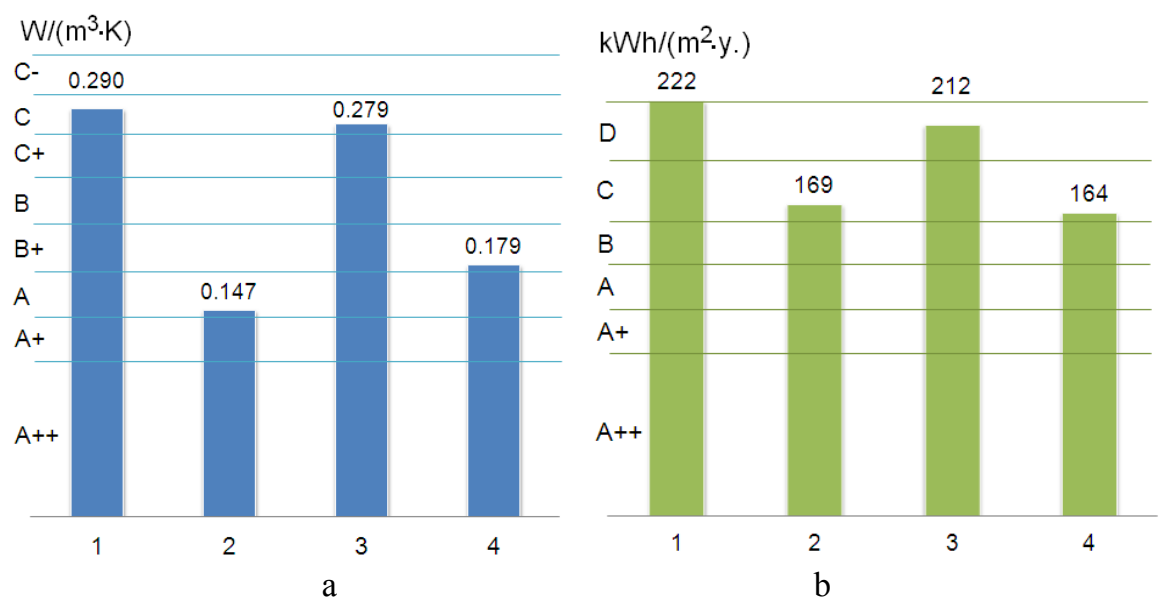

Fig. 5. Estimation of building energy efficiency class: a - heating ( 1 - required (standardized) level; 2 - designed level; 3 - actual level; 4 - expected level after thermorenovation; classes: A - very high; $\mathrm{B}$ - high; $\mathrm{C}$ - normal); $\mathrm{b}$ - total energy consumption (1 - required (standardized) level; 2 - designed level; 3 - actual level; 4 - expected level after thermorenovation; classes: A++ - highest; $\mathrm{A}^{+}-$ highest; A - very high; B - high; $\mathrm{C}$ - raised; D - normal).

According to the figure 5 a for buildings under construction the energy efficiency class is $\mathrm{C}$ (normal). Use of energy saving technologies at design allows raising the building energy efficiency class to level "A" (very high). At construction various deviations from the design reduce the building energy efficiency class. Deviation of the actual level of energy consumption from design level is $90 \%$. After thermorenovation the expected level of energy consumption approaches design level. Deviation of the expected level of energy consumption from design level is approximately $22 \%$. The results of energy efficiency class 
assessment for the building based on total energy consumption during the annual year are given below.

According to the figure $5 \mathrm{~b}$ for buildings under construction the energy efficiency class is $\mathrm{D}$ (normal). Use of energy saving technologies at design allows raising the building energy efficiency class to level " $C$ " (raised). At construction various deviations from the design reduce the building energy efficiency class. Deviation of the actual level of energy consumption from design level is about $25 \%$. After thermorenovation the expected level of energy consumption approaches design level. Deviation of the expected level of energy consumption from design level is minus $3 \%$.

Comparing results of the building energy efficiency classes assessment based on various standards, i.e. on heating and annual total energy consumption, it is possible to note that energy consumption indices of the building will be approved with standard requirements at various stages of lifecycle of the building. Inequation (1) is fulfilled, so the building inspected conforms to the energy efficiency requirement. Thermorenovation of the building based on ventilating and infiltration heat losses reduction through a building envelope allows reducing annual energy consumption. Energy efficiency assessment based on the total annual energy consumption of building, including energy indices for heating and a ventilation, hot water supply and electricity supply, in comparison with heating is more complete. The account of various components in building energy balance completely corresponds to modern direction of researches on energy conservation and thermal comfort enhancement in buildings [3].

\section{Conclusions}

The research purpose is complex analysis of energy efficiency in operated high-rise residential building. Many actions for building energy efficiency are realized according to the project; mainly it is the effective building envelope and engineering systems. Based on results of measurements the energy indicators of the building during annual period have been calculated. The main reason of increase in heat losses consists in the raised infiltration of external air in the building through a building envelope owing to the increased air permeability of windows and balcony doors (construction defects). For ensuring the normalized air exchange at the equipment of rooms only with the exhaust shaft ventilation it is necessary to provide adjustable affluent devices in windows. It is also necessary to reduce as much as possible energy consumption by external air infiltration through the building envelope.

Comparing results of the building energy efficiency classes assessment based on various standards, i.e. on heating and annual total energy consumption, it is possible to note that energy consumption indices of the building will be approved with standard requirements at various stages of lifecycle of the building. Thermorenovation of the building based on ventilating and infiltration heat losses reduction through a building envelope allows reducing annual energy consumption. Energy efficiency assessment based on the total annual energy consumption of building, including energy indices for heating and a ventilation, hot water supply and electricity supply, in comparison with heating is more complete. The account of various components in building energy balance completely corresponds to modern direction of researches on energy conservation and thermal comfort enhancement in buildings [3].

\section{References}

1. V. N. Bogoslovskiy, Building Thermal Comfort, 248 (Moscow, Stroyizdat, 1979) 
2. Yu. A. Tabunshchikov, M. M. Brodach, Mathematical Simulation and Optimization of Thermal Efficiency for Buildings, 194 (Moscow, AVOK-PRESS, 2002)

3. Yu. A. Tabunshchikov, M. M. Brodach, N. V. Shilkin, Energy-Efficient Buildings, 200 (Moscow, AVOK-PRESS, 2003)

4. Yu. A. Matrosov, I. N. Butovsky, R. K. Watson, Case studies of energy consumption in residential buildings in Russia's middle belt area, Energy and Buildings, 20(3), 231241 (1994)

5. M. W. Opitz, L. K. Norford, Yu. A. Matrosov, I. N. Butovsky, Energy consumption and conservation in the Russian apartment building stock, Energy and Buildings, 25(1), 75-92 (1997)

6. Yu. A. Matrosov, L. K. Norford, M. W. Opitz, I. N. Butovsky, Standards for heating energy use in Russian buildings: a review and a report of recent progress, Energy and Buildings, 25(3), 207-222 (1997)

7. N. I. Vatin, D. V. Nemova, P. P. Rymkevich, A. S. Gorshkov, Influence of building envelope thermal protection on heat loss value in the building, Magazine of Civil Engineering, 8(34), 4-14 (2012)

8. N. Vatin, O. Gamayunova, Energy saving at home, Applied Mechanics and Materials, 672-674, 550-553 (2014)

9. N. Harmati, Z. Jakšić, N. Vatin, Energy consumption modeling via heat balance method for energy performance of a building, Procedia Engineering, 117, 924-937 (2015)

10. S. V. Korniyenko, Multifactorial forecast of thermal behavior in building envelope elements, Magazine of Civil Engineering, 52(8), 25-37 (2014)

11. S V Korniyenko, Applied Mechanics and Materials, 618, 509-513 (2014)

12. S. Korniyenko, Evaluation of thermal performance of residential building envelope, Procedia Engineering, 117(1), 191-196 (2015)

13. S. V. Korniyenko, N. I. Vatin, A. S. Gorshkov, Thermophysical field testing of residential buildings made of autoclaved aerated concrete blocks, Magazine of Civil Engineering, 64(4), 10-25 (2016)

14. S. Korniyenko, Advanced hygrothermal performance of building component at reconstruction of S. Radonezhskiy temple in Volgograd, MATEC Web of Conferences, 53, 01003 (2016)

15. V. Motuzienè, K. Valančius, G. Rynkun, Complex analysis of energy efficiency of public buildings: case study of VGTU, Magazine of Civil Engineering, 2(28), 9-17 (2012)

16. R. McKenna, E. Merkel, D. Fehrenbach, S. Mehne, W. Fichtner, Building and Environment, 62, 77-88 (2013)

17. W. O. Brown Nils, T. Malmqvist, W. Bai, M. Molinari, Building and Environment, 61, 140-148 (2013)

18. H. Sozer, Improving energy efficiency through the design of the building envelope, Building and Environment, 45(12), 2581-2593 (2010)

19. A. Roetzel, A. Tsangrassoulis, U. Building and Environment, 71, 165-175 (2014)

20. Q. J. Kwong, N. M. Adam, B. B. Sahari, Energy and Buildings, 68, 547-557 (2014) 